\title{
The Harpy Eagle and the Amazon rainforest in Brazilian federal law - thoughts on environmental law and the conservation of birds of prey and their habitat*
}

\author{
Johan C Knobel \\ $B L C L L D$ \\ Professor of Private Law, University of South Africa
}

\section{OPSOMMING}

Die Harpy-arend en die Amasone-reënwoud in die Brasiliaanse federale reg gedagtes oor die omgewingsreg en die bewaring van roofvoëls en hulle habitat

Die regsbeskerming van die Harpy-arend en die Amasone-reënwoud in die Brasiliaanse federale reg word krities in oorsig geneem en insigte wat van algemene toepassing op die regsbeskerming van roofvoëls en hulle habitat is, word daaruit geput. Die Harpy-arend word bedreig deurdat individuele voëls gejag en gevang word en deur habitatvernietiging. Die Amasonereënwoud word onder andere deur ontbossing en aardverwarming bedreig. Die Harpy-arend se bewaringstatus ingevolge die Brasiliaanse federale reg is bevredigend. Omvattende wetgewing is ook in plek om vir die bewaring van die Amasone-reënwoud voorsiening te maak, maar daar is vraagtekens oor die effektiwiteit daarvan, veral na die promulgering van 'n nuwe Código Florestal (Woud-kode), wat swakker beskerming as sy voorganger bied. Teenstand van 'n invloedryke landbou-belangegroep en soms gebrekkige regshandhawing ondermyn die effektiwiteit van die Woud-kode. Aan die ander kant het omgewingsowerhede daarin geslaag om die tempo van ontbossing te verlaag, onder andere deur die effektiewe benutting van tegnologiese hulpmiddele en deur die aanwending van strafregtelike sanksies waarvoor Brasiliaanse wetgewing voorsiening maak. Regsgeleerdes, soos lede van die Ministério Público (die openbare vervolgingsgesag) en die regbank, speel 'n positiewe rol in die implementering van die omgewingreg in Brasilië. Omdat reënwoude aardverwarming teenwerk, is die regsbeskerming van die Amasone van internasionale belang. Die effektiewe regsbeskerming van groot roofvoëls verg 'n tweeledige aanslag: regsbeskerming teen direkte bedreigings soos jag, asook regsbeskerming van habitat. Die regsbeskerming van roofvoëls kan ook die bewaring van woudhabitatte bevorder, enersyds deur die roofvoëls se ekologiese rol as karnivore, en andersyds as vlagskipspesies in bewaringsinisiatiewe. Die doeltreffende regsbeskerming van spesies en hulle habitatte sal toenemend internasionale samewerking verg.

* Valuable critical comments by anonymous reviewers and financial support by the National Research Foundation of South Africa are gratefully acknowledged.

How to cite: Knobel 'The Harpy Eagle and the Amazon rainforest in Brazilian federal law - thoughts on environmental law and the conservation of birds of prey and their habitat' 2017 De Jure 204-220 http://dx.doi.org/10.17159/2225-7160/2017/v50n2a 


\section{Introduction}

The Harpy Eagle ${ }^{1}$ has been described by ornithologists as the most formidable avian predator in the world. ${ }^{2}$ It is one of the largest and probably the most powerful of all the actively hunting 3 raptors, or birds of prey. ${ }^{4}$ Its main habitat is South and Central American rainforest. ${ }^{5}$ The Amazon is the largest tropical rainforest in the world. It occupies an estimated 5500000 square kilometers, which constitute 56 per cent of all the broadleaf forests on earth. ${ }^{6}$ It spans across 9 South American countries, ${ }^{7}$ with the largest portion situated in Brazil. ${ }^{8}$ As one of the world's largest hunting raptors and the largest tropical rainforest respectively, the Harpy Eagle and the Amazon rainforest may both be described as giants of nature. They are intimately connected, insofar as the Harpy Eagle is an apex predator in the Amazonian ecosystem, and the Amazon is the most important forest for the global conservation of the Harpy Eagle. ${ }^{9}$

1 Harpia harpyja. See in general Brown and Amadon Eagles, Hawks And Falcons of The World Vol 2 (1968) 632-636; Del Hoyo, Elliot and Sargatal (eds) Handbook Of The Birds Of The World Vol 2 (1994) 191; Ferguson-Lees and Christie Raptors Of The World (2001) 717-719; BirdLife International 2017 http://datazone.birdlife.org/species/factsheet/harpy-eagle-harpia-harp yja (accessed 2017-03-03); Global Raptor Information Network 2017 http:// www.globalraptors.org/grin/SpeciesResults.asp?specID $=8040 \quad$ (accessed 2017-03-03); International Union for Conservation of Nature and Natural Resources 2016 http://dx.doi.org/10.2305/IUCN.UK.2016-3.RLTS.T226959 98A93537912.en (accessed 2017-03-03).

2 Brown and Amadon 632; Ferguson-Lees and Christie 718. The recorded weight of the Harpy Eagle is 4-9 kg (Ferguson-Lees and Christie 718). The two eagle species that are closest in terms of weight are Steller's Sea Eagle Haliaeetus pelagicus at 4.9-9 kg (Ferguson-Lees and Christie 408) and the Philippine Eagle Pithecophaga jefferyi at 4.7-8 kg (Ferguson-Lees and Christie 722). Scientific and English names used here follow Dickinson and Remsen The Howard Moore Complete Checklist Of The Birds Of The World Vol 1 (2013).

3 As opposed to scavenging, see eg Del Hoyo, Elliot and Sargatal (eds) 69.

$4 \quad$ Kemp 'What is a raptor?' in Newton (ed) Birds Of Prey (1990) 14.

5 Brown and Amadon 632; Del Hoyo, Elliot and Sargatal (eds) 191; FergusonLees and Christie 717-718; BirdLife International 2017 http://datazone. birdlife.org/species/factsheet/harpy-eagle-harpia-harpyja (accessed 2017-0303); Global Raptor Information Network 2017 http://www.globalraptors.org/ grin/SpeciesResults.asp?specID = 8040 (accessed 2017-03-03); International Union for Conservation of Nature and Natural Resources 2016 http:// dx.doi.org/10.2305/IUCN.UK.2016-3.RLTS.T22695998A93537912.en (accessed 2017-03-03).

6 Barbosa Guardians of the Amazon Rainforest: Environmental organizations and development (2015) 1.

7 Bolivia, Brazil, Colombia, Ecuador, French Guyana, Guyana, Peru, Surinam and Venezuela.

8 Brazil contains $69 \%$ of the Amazon drainage basin, in which the Amazon rainforest is situated; supra $\mathrm{n} 6$ at 1 .

9 Ferguson-Lees and Christie 719; International Union for Conservation of Nature and Natural Resources 2016 http://dx.doi.org/10.2305/IUCN.UK. 2016-3.RLTS.T22695998A93537912.en (accessed 2017-03-03). 
Both the Harpy Eagle and the Amazon Rainforest are under threat. The Harpy Eagle has disappeared from vast parts of its historically known range of distribution, ${ }^{10}$ and millions of hectares of the Amazon have been lost to human development or destruction. ${ }^{11}$

This contribution provides a critical overview of the protection that has been bestowed upon the Harpy Eagle and the Amazon rainforest under Brazilian federal law. ${ }^{12}$ To provide context, the overview is preceded by an introductory account of the basic, and interrelated, conservation challenges faced by the Harpy Eagle and the Amazon rainforest in Brazil. Overviews of enforcement and compliance realities and challenges follow and lead on to a discussion of pertinent aspects of the legal protection of the Harpy Eagle and the Amazon, with the aim of producing important insights of general application in respect of the legal conservation of birds of prey and their habitats.

\section{Conservation Challenges}

\section{Conservation Challenges Facing the Harpy Eagle}

In global terms, the Harpy Eagle probably has a population in the range of 20000 to 50000 individuals and is not currently regarded as an Endangered Species on a global scale. However, Harpy Eagle populations are suspected to be declining 'moderately rapidly' and its worldwide distribution range is shrinking. In Brazil, the Amazon still harbours an apparently substantial Harpy Eagle population. ${ }^{13}$ The International Union for Conservation of Nature and Natural Resources (IUCN), in consultation with BirdLife International, lists the Harpy Eagle as globally Near-Threatened in its Red List. These conservation non-governmental organisations furthermore project that the Harpy Eagle will suffer a habitat loss of 27.6 to $45.5 \%$ and that the species is likely to decline by

10 Ferguson-Lees and Christie 717; International Union for Conservation of Nature and Natural Resources 2016 http://dx.doi.org/10.2305/IUCN.UK. 2016-3.RLTS.T22695998A93537912.en (accessed 2017-03-03).

11 Roughly $1299593 \mathrm{sq} \mathrm{km}$ of the Amazon have been cleared by 2012; supra n 6 at 1 .

12 Brazil is a federation of 26 states, a federal district and municipalities. Federal law, rather than state law, generally plays a more dominant part in environmental conservation, especially in the Amazonian states; see McAllister Making Law Matter: Environmental Protection And Legal Institutions In Brazil (2008) 22.

13 BirdLife International $2017 \mathrm{http} / / /$ datazone.birdlife.org/species/factsheet/ harpy-eagle-harpia-harpyja (accessed 2017-03-03); International Union for Conservation of Nature and Natural Resources 2016 http://dx.doi.org/ 10.2305/IUCN.UK.2016-3.RLTS.T22695998A93537912.en (accessed 201703-03). The Harpy Eagle also occurs in smaller numbers in other habitats, such as the Pantanal floodplain and forest enclaves in Cerrado (woody savanna). In the species-rich, but highly fragmented, Atlantic Forest of Brazil, Harpy Eagle numbers have been severely reduced. See Aguiar-Silva, Sanaiotti and Luz 'Food habits of the Harpy Eagle, a top predator from the Amazonian forest canopy' 2014 48(1) Journal of Raptor Research 25. 
25 to $30 \%$ over three generations. ${ }^{14}$ Therefore, the Harpy Eagle's population and distribution trends warrant concern and legal and other conservation responses are appropriate.

The most important known anthropogenic threats experienced by the Harpy Eagle may be broadly classified into direct threats, that is, by hunting and live capture of individual birds; and indirect threats, mainly habitat destruction. ${ }^{15}$ The hunting and live capture of Harpy Eagles may be motivated by such diverse objectives as the securing of trophies, obtaining live specimens for zoos or as pets, retaliation for and prevention of domestic stock losses, and so forth. ${ }^{16}$ Even curiosity on the part of persons who have never or seldom seen Harpy Eagles has been recorded as a motive to kill the eagles. ${ }^{17}$

Habitat destruction is regarded as the most serious general threat faced by wildlife. ${ }^{18}$ The Harpy Eagle has not escaped this trend. Because the Amazon rainforest is a globally important component of the worldwide distribution of the Harpy Eagle, the conservation challenges faced by the Amazon will now be considered.

\section{Conservation Challenges Facing the Amazon Rainforest}

The Amazon is so much larger than any other rainforest that it is probably further away from total destruction than any other rainforest on earth. Historically, the interior of the Amazon has been largely inaccessible, and the forest enjoyed a comparatively large measure of immunity against the destructive activities of human populations for a long time. ${ }^{19}$ Human access was originally largely limited to waterborne transport along rivers. However, in more recent times, the Amazon has become vulnerable to deforestation and degradation. In 2001, scientists claimed that the Amazon had the highest absolute rate of forest destruction in the world, averaging nearly 200 million hectares per year. ${ }^{20}$ By 2012, an estimated 757661 square kilometres of the Brazilian part of the Amazon have been cleared, representing 18.6 percent of the

14 BirdLife International 2017 http://datazone.birdlife.org/species/factsheet/ harpy-eagle-harpia-harpyja (accessed 2017-03-03); International Union for Conservation of Nature and Natural Resources 2016 http://dx.doi.org/ 10.2305/IUCN.UK.2016-3.RLTS.T22695998A93537912.en (accessed 201703-03).

15 Aguiar-Silva, Sanaiotti and Luz 2014 48(1) Journal of Raptor Research supra n 13 at 25 .

16 Global Raptor Information Network 2017 http://www.globalraptors.org/grin/ SpeciesResults.asp?specID = 8040 (accessed 2017-03-03).

17 Trinca, Ferrari and Lees 'Curiosity killed the bird: arbitrary hunting of Harpy Eagles Harpia harpyja on an agricultural frontier in southern Brazilian Amazonia' 200830 Cotinga 12-15.

18 Owens and Bennett 'Ecological basis of extinction risk in birds: habitat loss versus human persecution and introduced predators' 200079 Proceedings of the National Academy of Sciences 12145.

19 Bryner 'Brazil's green court: environmental law in the Superior Tribunal de Justiça (High Court of Brazil)' 2012 Pace Envtl L Rev 473.

20 Laurance et al 'The future of the Brazilian Amazon' 2001291 Science 438. 
Brazilian Amazon. ${ }^{21}$ Advancement of agricultural interests such as the acquisition of ranchland for livestock and large-scale cropland cultivation, ${ }^{22}$ road construction, human settlement and the construction of dams for hydro-electrical schemes constitute some of the major causes of deforestation. ${ }^{23}$ The construction of new roads continues to open up vast new areas to human exploration and exploitation. ${ }^{24}$

\section{Legal Protection Under Brazilian Federal Law}

\section{Protection of the Harpy Eagle in Brazilian Federal Law}

A chapter of the Constitution ${ }^{25}$ of Brazil is devoted to the environment. ${ }^{26}$ It states that all have the right to an ecologically balanced environment, and the state and the citizenry have a duty to defend and preserve it for present and future generations. ${ }^{27}$ To ensure the effectiveness of this right, the state has the responsibility to protect the fauna and flora by

21 Supra $\mathrm{n} 6$ at 1 . Combined with the estimated deforestation in Bolivia, Colombia, Ecuador, French Guyana, Guyana, Peru, Surinam and Venezuela, roughly 1299593 square kilometers of the entire Amazon have been cleared by 2012.

22 Soy beans and beef are two of the most important agricultural products in Brazil and both are produced at the expense of rainforest in many areas; see Crawford and Pignataro 'The insistent (and unrelenting') challenges of protecting biodiversity in Brazil: finding "the law that sticks" 2007 39(1) University of Miami Inter-American Law Review 16-19.

23 Crawford and Pignataro 2007 39(1) University of Miami Inter-American Law Review supra n 22 at 6; Fearnside "Environmental and social impacts of hydroelectric dams in Brazilian Amazonia: implications for the aluminum industry' 201677 World Development 48-65; Mongabay 2016 https:// news.mongabay.com/2016/03/bndes-a-bank-loans-billions-to-tame-southamericas-wild-waters/ (accessed 2017-03-23).

24 Barber et al 'Roads, deforestation and the mitigating effect of protected areas in the Amazon' 2014177 Biological Conservation 203-208. A longterm study on the biological dynamics of forest fragments conducted near Manaus in the Brazilian Amazon has shown that the more fragmented a forest becomes and the smaller the forest fragments become as a result of deforestation, the greater the loss of biodiversity becomes inside the forest fragments; see eg Laurance et al 'The fate of Amazonian forest fragments: a 32-year investigation' 2011144 Biological Conservation 56-65.

25 See, on the role of the Constitution in respect of the environment, Bryner 2012 Pace Envtl L Rev supra n 19 at 480-481; Drummond and BarrosPlatiau 'Brazilian environmental laws and policies, 1934-2002: a critical overview' 2006 28(1) Law and Policy 95; Daibert 'Historical views on environment and environmental law in Brazil' 2009 Geo Wash Intl L Rev 836-837; Fernandes 'Law, politics and environmental protection in Brazil' 1992 4(1) Journal of Environmental Law 52-53; McAllister 24-25; Patriota 'An introduction to Brazilian environmental law' 2009 Geo Wash Intnl L Rev 612-614.

26 Chapter VI.

27 Article 225; see also Michigan State University College of Law 2016 https:// www.animallaw.info/intro/brazil (accessed 2017-03-03); Michigan State University College of Law 2016 https://www.animallaw.info/statute/brazilconstitutional-provision-animal (accessed 2017-03-03). 
legislation that prohibits practices which are a risk to their ecological function, cause the extinction of species or subject animals to cruelty. ${ }^{28}$

Law 5.197 of 1967 established comprehensive protection for indigenous fauna. ${ }^{29}$ It provided that wild animals, as well as their nests, shelters and natural breeding sites are property of the state, and their use, persecution, destruction, hunting or harvesting is prohibited. ${ }^{30}$ This protection was strengthened by the Environmental Crimes Law, ${ }^{31}$ which criminalises and establishes penalties for the killing, pursuing, hunting, catching and use of resident or migratory wildlife animal species without authorisation or a licence. ${ }^{32}$ Wildlife animal species are defined as all indigenous species, migratory or otherwise, terrestrial or aquatic, whose life cycle takes place, in whole or partially, within the Brazilian territory or in Brazilian jurisdictional waters. ${ }^{33}$ The penalty is imprisonment of six months to one year and a fine. ${ }^{34}$ Other acts that attract the same penalties are the obstructing of the procreation of fauna; modification, damaging or destruction of nests, refuges or natural breeding areas; and trading in wild animals. ${ }^{35}$ The penalties will be increased by 50 percent under certain circumstances, inter alia if the crime is committed against a rare species or one considered to be endangered, even if this pertains only at the site where the crime is committed; if the crime is committed in a conservation area; or if the crime is committed using methods or equipment capable of causing mass destruction. ${ }^{36}$ If the crime is committed in the form of professional hunting, the penalty may increase threefold. ${ }^{37}$ Killing an animal is not a crime if it is done in necessity to satisfy the hunger of the perpetrator or his family; to protect agriculture,

28 Article 225 par 1(vii); see also Michigan State University College of Law 2016 https://www.animallaw.info/statute/brazil-constitutional-provision-ani mal (accessed 2017-03-03).

29 Daibert 2009 Geo Wash Intl L Rev supra n 25838.

30 Article 1; art 2 also prohibits professional hunting. Some exceptions are made in subsequent provisions.

31 Law 9.605 of 1998. See in general Benjamin 'Criminal law and the protection of the environment in Brazil' 1998 Fifth International Conference on Environmental Compliance and Enforcement $227 \mathrm{https}: / / w w w . i n e c e . o r g /$ assets/Publications/579f99e064d12_ThemeCriminalLawAndTheProtection Of_Full.pdf (accessed 2017-03-20); Drummond and Barros-Platiau 2006 28(1) Law and Policy supra n 25 at 100; Michigan State University College of Law 2016 https://www.animallaw.info/intro/brazil (accessed 2017-03-03). An English translation of the Environmental Crimes Law is available at Michigan State University College of Law 2016 https://www.animallaw.info/ statute/brazil-crimes-brazilian-environmental-crimes-law (accessed 2017 03-03). The predecessor of Law 9.605 in the field of the conservation of fauna was the Animal Protection Act, Law 5.197 of 03/01/1967; see Drummond and Barros-Platiau 2006 28(1) Law and Policy supra n 25 at 90-91.

32 Article 29

33 Article 29(3).

34 Article 29.

35 Article 29(1).

36 Article 29(4).

37 Article 29(5); Benjamin 1998 Fifth International Conference on Environmental Compliance and Enforcement supra n 31 at 230. 
orchards and herds if authority has been granted by a competent authority; or in case of dangerous animals. ${ }^{38}$

The Harpy Eagle is classified as 'Vulnerable' in the National List of Brazilian Fauna Species Threatened With Extinction, ${ }^{39}$ which has been compiled by the Chico Mendes Institute for Nature Conservation, an office of the Brazilian Ministry of the Environment. This Brazilian list, therefore, allocates the Harpy Eagle to a more serious category of threat than the IUCN Red List. ${ }^{40}$ The inclusion of the Harpy Eagle in the Brazilian list will inter alia mean that crimes under the Environmental Crimes Law against the Harpy Eagle will attract the harsher penalties provided for in respect of crimes to rare or endangered species.

Because the Harpy Eagle occurs naturally in low densities and is a slow breeder, even a small decline in the annual survival rate of adult birds can have a large negative effect on the size of the population. ${ }^{41}$ Large bird species with slow reproductive rates may be lost from otherwise suitable habitat if hunting and other anthropogenic factors reduce the average annual survival of adults and causing a population decline. ${ }^{42}$ For this reason, the targeted legal protection of the Harpy Eagle against human persecution, as detailed above, is important for its survival.

\section{Protection of the Amazon Rainforest in Brazilian Federal Law}

The Constitution of Brazil provides that the Brazilian Amazonian forest is a part of the national patrimony and that it shall be used under conditions prescribed by law that will ensure the preservation of the environment. ${ }^{43}$

38 Article 37.

39 Ordinance 444 of 17/12/2014, see http://www.icmbio.gov.br/portal/images/ stories/biodiversidade/fauna-brasileira/avaliacao-do-risco/PORTARIA_N\% C2 \%BA_444_DE_17_DE_DEZEMBRO_DE_2014.pdf (accessed 2017-03-20). See further the Ministry of the Environment 2017 http://www.mma.gov.br/ biodiversidade/especies-ameacadas-de-extincao/fauna-ameacada (accessed 2017-03-20).

40 As seen in par 21 above, the IUCN lists the Harpy Eagle as Nearthreatened. According to IUCN criteria, Vulnerable is a more serious category. Taxa that are classified as Vulnerable are regarded to face a high risk of extinction; see IUCN $2016 \mathrm{http} / / / \mathrm{www}$.iucnredlist.org/static/ categories_criteria_3_1 (accessed 2017-03-20).

41 Watson et al 'Trial restoration of the Harpy Eagle, a large, long-lived, tropical forest raptor, in Belize and Panama' 2016 50(1) Journal of Raptor Research 4.

42 Watson et al 2016 50(1) Journal of Raptor Research supra n 41 at 4; Owens and Bennett 2000 (79) Proceedings of the National Academy of Sciences supra 18 at $144-147$.

43 Article 225 par 4; see also Michigan State University College of Law 2016 https://www.animallaw.info/statute/brazil-constitutional-provision-animal (accessed 2017-03-03). 
Since 2001, the Código Florestal (Forest Code) ${ }^{44}$ requires landowners who own land in the Amazon to conserve the indigenous vegetation in so-called Legal Reserves that must constitute $80 \%$ of their land. ${ }^{45}$ If a greater portion of the land has already been deforested, the native vegetation must be restored at the landowners' expense to meet the required percentage. ${ }^{46}$ In addition, certain parts of the land, such as riparian land and hilltops and steep slopes, are designated as Areas of Permanent Preservation to conserve water resources and to combat erosion. ${ }^{47}$ According to this requirement, buffer strips of indigenous riparian vegetation (Riparian Protection Areas) must be left intact along watercourses. ${ }^{48}$ In rural areas, protection areas must also be left intact around natural ponds or lakes. ${ }^{49}$ Where land in the aforementioned zones have already been deforested by human occupation, the landowners have a duty to restore the native vegetation at their own

44 Originally Law 4.771 of 09/15/1965 modified by Provisional Measures 1.1511 of 06/25/1996 and 2.166-67 of 08/24/2001; currently Law 12.651 of 05/25/ 2012, modified by Law 12.727 and Decree 7.830 of 10/17/2012. Law 4.771 was promulgated in 1965 and was transformed into a conservationoriented body of legislation by a series of presidential decrees; see SoaresFilho et al 'Cracking Brazil's Forest Code' 2014344 Science 363. Law 4.771 was preceded by Decree 23.793 of 23/01/1934, which was also popularly known as the 'Forest Code'. While it stated in art 1 that forests were of common interest to all Brazilians, Decree 23.793 contained few preservationist provisions; see Drummond and Barros-Platiau 2006 28(1) Law and Policy supra n 25 at 87. Despite its name, the 'Code' is not a codification of statutes and is more accurately referred to as the 'Forest Law'. For historical background and evaluation, see Drummond and BarrosPlatiau 2006 28(1) supra n 25 at 87-90; Patriota 2009 Geo Wash Intnl L Rev supra n 25 at 614-615; Daibert 2009 Geo Wash Intnl L Rev supra n 25 at 825 831-832.

45 Originally Law 4.771 of $09 / 15 / 1965$ art 16; currently Law 12.651 of 05/25/ 2012 art 12; see further Soares-Filho et al 2014344 Science supra n 44 at 363. In spite of the name 'Forest Code' this statute also applies to other forms of native vegetation, such as grassland and Cerrado (savanna). Land situated in the Amazon receives a significantly higher degree of protection insofar as the Legal Reserve on land in most other biomes is required to constitute $20 \%$ of the property and in the Cerrado biome $35 \%$.

46 Originally under Law 4.771 of $09 / 15 / 1965$ art 16(5) to the full size of the Legal Reserve or to $50 \%$ if the property has been designated as a consolidation zone. Under the new Forest Code the restoration requirements differ; see below.

47 Soares-Filho et al 2014344 Science supra n 44 at 363.

48 The width of the Riparian Protection Areas depends on the width of the watercourses: $30 \mathrm{~m}$ for watercourses less than $10 \mathrm{~m}$ wide, $50 \mathrm{~m}$ for watercourses 10-50 m wide, $100 \mathrm{~m}$ for watercourses 50-200 m wide, $200 \mathrm{~m}$ for watercourses 200-600 m wide, and $500 \mathrm{~m}$ for watercourses wider than $600 \mathrm{~m}$; originally Law 4.771 of 09/15/1965 art 2; currently Law 12.651 of 05/25/2012 art 4

49 Such strips must be $100 \mathrm{~m}$ wide, unless the waterbodies have a surface area of 20 ha or smaller, in which case the required width of the protected zone is $50 \mathrm{~m}$; originally Law 4.771 of 09/15/1965 art 2; currently Law 12.651 of $05 / 25 / 2012$ art 4 
expense. ${ }^{50}$ Similar provisions require the setting aside of Areas of Permanent Preservation on hilltops and steep slopes (Hilltop Preservation Areas). For instance, native vegetation must be kept intact or, under the old Forest Code, restored on hilltops complying with certain criteria. Hilltops are defined as the areas situated higher than the lower two-thirds of the slope of the hill. ${ }^{51}$ The Environmental Crimes Law boosted compliance with the provisions of the Forest Code by providing for penalties for specific criminal offences against flora. ${ }^{52}$

After an agribusiness backlash, ${ }^{53}$ a new Forest Code ${ }^{54}$ was adopted that provides weaker protection for native vegetation. The provisions pertaining to the size of Legal Reserves and Riparian Protection Areas remain the same as under the previous code, but the restoration duty of the landowners in respect of illegally cleared vegetation no longer extends to the entire area of Legal Reserves. ${ }^{55}$ The Legal Reserve of Amazonian municipalities is also significantly reduced from $80 \%$ to $50 \%$ of the landholding if more than half of their surface area consists of protected areas. ${ }^{56}$ The parts of Riparian Protection Areas that need to be restored, are measured differently and are narrower than the Riparian Protection Areas themselves. ${ }^{57}$ The restoration duties of smaller

50 Originally Law 4.771 of $09 / 15 / 1965$ art 2; currently Law 12.651 of 05/25/ 2012 art 16(6). See Crawford and Pignataro 2007 39(1) University of Miami Inter-American Law Review supra n 22 at 25-27 for more detail on the position under Law 4.771 .

51 Originally CONAMA resolution 303 of 03/20/2002; currently Law 12.651 of $05 / 25 / 2012$ art 4. CONAMA is the National Environmental Council; see Drummond and Barros-Platiau 2006 28(1) Law and Policy supra n 25 at 93 94. Under the old Code, the first category of Hilltop Protection Areas are hilltops with a minimum height of $50 \mathrm{~m}$ measured from their base, a maximum height of $300 \mathrm{~m}$ and a mean slope of $17 \%$ or more. Similar provisions regulate the position for higher hills, mesas and escarpments complying with specified physical characteristics such as height, surface area and slope; see further Soares-Filho et al 2014 'Supplementary materials' http://science.sciencemag.org/content/suppl/2014/04/23/344. 6182.363.DC1 (accessed 2017-03-15).

52 Law 9.605 of 1998; see eg arts 40 and 49; Benjamin 1998 Fifth International Conference on Environmental Compliance and Enforcement supra $\mathrm{n} 31$ at 230; Nepstad et al 'Frontier governance in Amazonia' 2002 295 Science 631.

53 See par 42 below.

54 Law 12.651 of $05 / 25 / 2012$, modified by Law 12.727 and Decree 7.830 of 10/ $17 / 2012$

55 For instance, if the property adheres to a Rural Environmental Registry, the Riparian Protection Areas count towards the Legal Reserves; Law 12.651 of 05/25/2012 art 15; Soares-Filho et al $2014 \mathrm{http}: / /$ science.sciencemag.org/ content/suppl/2014/04/23/344.61 82.363.DC1 (accessed 2017-03-15).

56 Law 12.651 of 05/25/2012 art 12; Soares-Filho et al 2014344 Science supra n 44 at 363; Soares-Filho et al 2014 http://science.sciencemag.org/content/ supp1/2014/04/23/344.6182.363.DC1 (accessed 2017-03-15).

57 Law 12.651 of 05/25/2012 arts 61(6) and 61B; see further Soares-Filho et al 2014 http://science.sciencemag.org/content/suppl/2014/04/23/344.6182. 363.DC1 (accessed 2017-03-15). 
properties in respect of Protected Riparian Properties are also more lenient. ${ }^{58}$ Hilltop Protection Areas are also defined differently in the new Forest Code $^{59}$ and this change is calculated to have reduced the Hilltop Preservation Areas in Brazil by $87 \% .{ }^{60}$ There is furthermore no longer a restoration requirement in respect of Hilltop Preservation Areas. ${ }^{61}$

In addition, smaller properties, which may be as big as 440 hectares in the Amazon, receive amnesty for illegal deforestation of Legal Reserves up to 2008 under the new Code and the owners of such properties are relieved of the restoration duty that they had under the original Forest Code. ${ }^{62}$ The impact of this concession is considerable, as $90 \%$ of rural properties in Brazil now enjoy amnesty. ${ }^{63}$ In combination, the various concessions provided for under the new Forest Code are calculated to have reduced Brazil's 'environmental debt' in respect of Legal Reserves and Riparian Protection Areas, which have been cleared before 2008 , by $58 \% .{ }^{64}$ The total surface area that had to be restored has been reduced from $50 \pm 6$ million hectares to $21 \pm 1$ million hectares, of which a disproportionately large part is situated in the Amazon. ${ }^{65}$

\section{Aspects of Enforcement and Compliance}

\section{Enforcement and Compliance Realities}

Commentators agree that the Brazilian laws protecting biodiversity and natural vegetation are of a high standard or even trend-setting. ${ }^{66}$ However, opinions vary on the standard of enforcement of and compliance with these laws, and accordingly, opinions differ on the effectiveness of this legal protection. On the one hand, some commentators point out that Brazil shares in a phenomenon that is

58 Law 12.651 of 05/25/2012 arts 61(6) and 61B; Soares-Filho et al 2014344 Science supra $\mathrm{n} 44$ at 363; Soares-Filho et al 2014 http://science. sciencemag.org/content/suppl/2014/04/23/344.6182.363.DC1 (accessed 2017-03-15).

59 For instance, hilltops must now be higher than $100 \mathrm{~m}$ and have a slope of $25 \%$ or steeper to qualify for protection; Law 12.651 of $05 / 25 / 2012$ art 4; see further Soares-Filho et al $2014 \mathrm{http}: / /$ science.sciencemag.org/content/ supp1/2014/04/23/344.6182.363.DC1 (accessed 2017-03-15).

60 Soares-Filho et al 2014344 Science supra $n 44$ at 363.

61 Law 12.651 of 05/25/2012 art 4; see further Soares-Filho et al 2014 http:// science.sciencemag.org/content/suppl/2014/04/23/344.6182.363.DC1 (accessed 2017-03-15)

62 Law 12.651 of 05/25/2012 art 67; see also art 12 and Soares-Filho et al 2014 http://science.sciencemag.org/content/suppl/2014/04/23/

344.6182.363.DC1 (accessed 2017-03-15).

63 Soares-Filho et al 2014344 Science supra n 44 at 363.

64 Soares-Filho et al 2014344 Science supra $n 44$ at 363.

65 Soares-Filho et al 2014344 Science supra n 44 at 363; Soares-Filho et al 2014 http://science.sciencemag.org/content/suppl/2014/04/23/344.6182. 363.DC1 (accessed 2017-03-15).

66 Drummond and Barros-Platiau 2006 28(1) Law and Policy supra n 25 at 100-102; Fernandes 1992 4(1) Journal of Environmental Law supra $\mathrm{n} 25$ at 42; McAllister 420. 
typical of environmental protection in many developing countries: the laws are adequate, but enforcement and compliance are weak. ${ }^{67}$ One author typifies the prevailing scenario as one characterised by strong laws, but weak agencies. ${ }^{68}$

On the other hand, authors also point out positive trends. Several government agencies play an important part in enforcing environmental law and policy. ${ }^{69}$ Modern technology is used extensively and effectively to gather evidence of transgressions. To detect illegal logging of natural forest vegetation, remote sensing is employed. ${ }^{70}$ Molecular forensics have been employed in wildlife crime cases. ${ }^{71}$ In respect of illegal hunting, capture and trading of animals, transgressors are tracked down inter alia by using the internet, particularly Facebook and YouTube. ${ }^{72}$

A very interesting positive aspect of enforcement and compliance, and one that is all too frequently lacking in developing and some developed countries, is the active and positive part played by lawyers in the enforcement of environmental law in Brazil. In this regard, McAllister highlights the role of the Ministério Público, the federal prosecuting authority in Brazil. ${ }^{73}$ McAllister argues that the Ministério Público has contributed in three important ways to the effectiveness of environmental enforcement in Brazil. First, it has replaced a culture of impunity, which had been undermining compliance, with a perception

67 See eg Bryner 2012 Pace Envtl L Rev supra n 19 at 534; Drummond and Barros-Platiau 2006 28(1) Law and Policy supra n 25 at 100-102; Da Silva and Bernard 'Inefficiency in the fight against wildlife crime in Brazil' 2016 50(3) Oryx 468-473; Guedes 'The environmental issue in Brazil: a matter of principles' 20142 Panorama of Brazilian Law 263-264; Hirakuri Can Law Save The Forest? Lessons From Finland And Brazil (2002) 2.

68 McAllister 20 and further.

69 See eg Banerjee and Macpherson 'Towards a policy of sustainable forest management in Brazil: a historical analysis' 2009 18(2) Journal of Environment and Development 142-144; Drummond and Barros-Platiau 2006 28(1) Law and Policy supra n 25 at 91-96; McAllister 'Sustainable consumption governance in the Amazon' 200838 Environmental Law Reporter 10876-10877.

70 Assunçao, Gandour and Rocha 'Deterring deforestation in the Brazilian Amazon: environmental monitoring and law enforcement' 2013 Climate Policy Initiative https://climatepolicyinitiative.org/wp-content/uploads/2013/ 05/DETERring-Deforestation-in-the-Brazilian-Amazon-Environmental-

Monitoring-and-Law-Enforcement-Executive-Summary.pdf (accessed 2017 03-20); Nepstad et al 2002295 Science supra n 52 at 631.

71 Sanches 'Illegal hunting cases detected with molecular forensics in Brazil' 2012 3(17) Investigative Genetics http://investigativegenetics.biomed central.com/articles/10.1186/2041-2223-3-17 (accessed 2017-03-23).

72 IBAMA 2017 http://www.ibama.gov.br/index.php?option=com_content\& view $=$ article\&id $=99$ : crimes-ambientais-identificados-pela-internet-soma m-r-3-milhoes-em-multas\&catid $=58 \&$ Itemid $=271$ (accessed 2017-03-20).

73 McAllister 420 et seq; for a critical evaluation see Crawford 'Defending public prosecutors and defining Brazil's environmental 'public interest': a review of Lesley McAllister's Making Law Matter: Environmental Protection And Legal Institutions In Brazil" 2009 Geo Wash Intl L Rev 627 et seq. See further Hochstetler and Keck Greening Brazil: Environmental Activism In State And Society (2007) 51-57. 
that even the powerful in government and the private sector could be held accountable for environmental wrongs. ${ }^{74}$ Second, it has assumed the function of holding even the environmental agencies themselves, which constitute a part of the executive arm of government, accountable. $^{75}$ Third, it has improved access to the courts in environmental matters and has itself served as a forum for the resolution of environmental disputes. ${ }^{76}$ Another contribution of jurists to the enforcement of environmental law, highlighted by Benjamin and Bryner, is the role of the judiciary. ${ }^{77}$ Members of the judiciary have interpreted and applied environmental laws in a manner that maximises environmental protection. ${ }^{78}$ In essence, the rule of law may be said to have been strengthened in the field of environmental protection. ${ }^{79}$

Brazilian environmental law and policy have been shown by scientific analysis to have contributed to a lowering of deforestation rates in the Amazon. ${ }^{80}$ The activities of the environmental police, such as the issuing of fines, have also had an impact in lowering deforestation rates. ${ }^{81}$ In particular, the penalties provided for by the Environmental Crimes Law have been credited as contributing to effective enforcement. ${ }^{82}$

\section{Opposition Against Conservation Initiatives}

From the outset, conservation efforts in the Amazon were met with opposition. Advocating rainforest conservation in the Amazon could even endanger human life, as exemplified by the murder of activist Chico Mendes. ${ }^{83}$ Mendes pioneered a concept of so-called extractive reserves, where indigent forest-living people could make a living from the

74 McAllister 85 et seq; McAllister 'Of environmental enforcement and compliance: a reply to Professor Crawford's review of Making Law Matter: Environmental Protection And Legal Institutions In Brazil' 2009 Geo Wash Intl L Rev 659.

75 McAllister 121 et seq; McAllister 2009 Geo Wash Intl L Rev supra $\mathrm{n} 74$ at 660

76 McAllister 152 et seq; McAllister 2009 Geo Wash Intl L Rev supra n 74 at 659.

77 Benjamin 'We, the judges, and the environment' 2012 Pace Envtl L Rev 582; Bryner 2012 Pace Envtl L Rev supra n 19 at 470.

78 Bryner 2012 Pace Envtl L Rev supra n 19 at 485-531.

79 McAllister 12-13.

80 Assunçao, Gandour and Rocha 2012 http://climatepolicyinitiative.org/wpcontent/uploads/2012/03/Deforestation-Prices-or-Policies-Working-

Paper.pdf (accessed 2017-03-03); Nepstad et al 'Slowing Amazon deforestation through public policy and interventions in beef and soy supply chains' 2014344 Science supra 1120.

81 Hargrave and Kis-Katos 'Economic causes of deforestation in the Brazilian Amazon; a panel data analysis for the 2000s' 201354 Environmental and Resource Economics 498-490.

82 Nepstad et al 2002295 Science supra $n 52$ at 631

83 Daibert 2009 Geo Wash Intnl L Rev supra n 25 at 836; Environmental Defense Fund 2017 https://www.edf.org/climate/chico-mendes-legacy (accessed 2017-03-17); Evans 2013 http://blog.cifor.org/17295/martyr-ofthe-amazon-the-legacy-of-chico-mendes?fnl=en (accessed 2017-03-17); Keck 'Social equity and environmental politics in Brazil: lessons from the rubber tappers of Acre' 1995 27(4) Comparative Politics 409-412. Since 
sustainable extraction of natural resources, in that case rubber, from indigenous rainforest. He initiated a movement that has been described as the 'world's first tropical forest conservation initiative advanced by forest peoples themselves'. 84 Mendes's activism was in conflict with government policy that favoured forest clearing at the time and also antagonised powerful businesspeople with vested interests in forest clearing. Mendes was shot dead in 1988. His murder was highly publicised and this gave the conservation movement, which had been initiated by him, a further impetus. ${ }^{85}$

It is self-evident that the Forest Code dramatically limits landowner's rights in respect of their properties, and that it places a heavy burden on landowners by imposing a duty to restore native vegetation at own cost. $^{86}$ These inroads into the rights of landowners followed in the wake of Brazilian land reform legislation which provided that private property attained its full social function only if it combined fair distribution, adequate use and conservation of natural resources. ${ }^{87}$ This meant that the wasteful use of natural resources became a legal reason to restrict private rights over land, which was revolutionary in Brazil at the time. ${ }^{88}$ However, these measures could not make the legal protection of rainforest on private land unassailable.

A politically powerful agribusiness lobby, referred to colloquially as the ruralistas, exerted pressure for changes to the far-reaching provisions of the Forest Code of $1965 .{ }^{89}$ The resignation, in 2008, of an environmental minister with a strong record of rainforest conservation was probably symptomatic of a loss of momentum on the side of conservationists in the face of the growing agribusiness backlash. ${ }^{90}$ The new Forest Code,

1985, almost 1000 persons have reputedly been murdered in land disputes in the Brazilian Amazon; Evans 2013 http://blog.cifor.org/17295/ martyr-of-the-amazon-the-legacy-of-chico-mendes?fnl = en (accessed 2017 03-17); see further The Guardian 2013 https://www.theguardian.com/ environment/blog/2013/apr/02/chico-mendes-killings-amazon (accessed 2017-03-17).

84 Environmental Defense Fund 2017 https://www.edf.org/climate/chicomendes-legacy (accessed 2017-03-17). See further Keck 1995 27(4) Comparative Politics supra n 83 at 417.

85 Evans 2013 http://blog.cifor.org/17295/martyr-of-the-amazon-the-legacy-ofchico-mendes?fnl $=$ en accessed 2017/03/17).

86 For a discussion of the problematic interface between traditional concepts of property and nature conservation in Brazil; see Crawford and Pignataro 2007 39(1) University of Miami Inter-American Law Review supra n 22 at 19. 27; Fernandes 1992 4(1) Journal of Environmental Law supra $\mathrm{n} 26$ at 46-47; Sarlet and Fensterseifer 'Brazil' in Kotzé and Paterson (eds) The Role of The Judiciary In Environmental Governance (2009) 257-258.

87 Law 4.504 of 30/11/1962, popularly known as the Land Statute, see Drummond and Barros-Platiau 2006 28(1) Law and Policy supra n 25 at 89; Daibert 2009 Geo Wash Intnl L Rev supra n 25 at 830-831.

88 Drummond and Barros-Platiau 2006 28(1) Law and Policy supra $n 25$ at 89.

89 EcoAméricas 2012 “Ruralistas' prevail in Brazil’s Forest Code battle http:// www.ecoamericas.com/en/story.aspx?id = 1338 (accessed 2017-03-23).

90 New York Times 2008 http://www.nytimes.com/2008/05/16/world/ameri cas/16brazil.html?ref $=$ world\&_r $=0$ (accessed 2017-03-20). 
with its significant concessions in favour of development and deforestation at the cost of rainforest conservation, was adopted in 2012. ${ }^{91}$ The new Forest Code has drawn criticism from nongovernmental organisations and the scientific community. ${ }^{92}$

\section{Discussion}

The conservation status of the Harpy Eagle, contextualised against the conservation threats it faces, confirms a key premise for the legal protection of birds of prey in general. It illustrates clearly that effective legal protection of large birds of prey usually requires a two-pronged approach. First, effective legal protection of the habitat of the birds of prey is essential. No legal intervention on behalf of a bird of prey species is likely to succeed in the long run if effective habitat protection is lacking. How difficult the conservation of habitat can be, is clearly demonstrated by the struggle to ascertain a secure, legally protected future for the Amazon rainforest. Second, the legal protection of habitat must be supplemented by more species-specific legal provisions protecting species against specific threats such as killing and capturing. The mobility of birds often make such species-specific protection for birds arguably more important than, for instance, in the case of large mammals, which may to a greater or lesser degree be confined to protected areas by physical barriers such as fences.

The importance of the conservation of the Amazon for the survival of the Harpy Eagle should be self-evident. However, effective legal conservation of the Harpy Eagle may also strengthen the conservation of the Amazon. The eagle fulfils a key role in the Amazon ecology as an apex predator, and removal of the eagle from the ecosystem could impact negatively on the health of the system in currently unforeseen ways. In most regions where it occurs, the Harpy Eagle preys primarily on arboreal herbivorous mammals that feed on the leaves of forest trees. Such herbivorous animals can have a significant impact on forest regeneration and this means that predators such as the Harpy Eagle render an important ecosystem service. ${ }^{93}$ To safeguard the long-term health of the Amazon ecology, the effective legal protection of the eagle

91 See par 32 above.

92 Metzger et al 'Brazilian law: full speed in reverse?' 2010329 Science 276277; Purdom and Nokes 2014 'Brazil repeals Forest Code and deforestation accelerates' https://eponline.com/articles/2014/01/08/brazil-repeals-forestcode-and-deforestation-accelerates.aspx (accessed 2017-03-03).

93 Aguiar-Silva, Sanaiotti and Luz 2014 48(1) Journal of Raptor Research supra $\mathrm{n} 13$ at 30 . A study in Venezuela found an association between and absence of large predators and decreased tree diversity and concluded that a viable guild of predators was fundamental to maintaining biodiversity; Terborgh et al 'Vegetation dynamics of predator-free land-bridge islands' 200694 Journal of Ecology 262. On the other hand, the fact that the Harpy Eagle also preys on fruit-eating animals, which may perform a valuable service as seed-dispersing agents, should perhaps also be taken into account to avoid a too simplistic analysis. 
is arguably prudent and in accordance with the precautionary principle. $^{94}$

Conservation of the Harpy Eagle could furthermore contribute to the conservation of the Amazon by fulfilling the role of a so-called flagship species. ${ }^{95}$ A flagship species is a species that is sufficiently charismatic in the eyes of the public that it can become a powerful symbol and leading element in a conservation campaign. ${ }^{96}$ Conservation initiatives can, and often are, driven from the top by governments and they typically employ legislation as a coercive means to do this. However, conservation initiatives, including conservation laws, are most likely to succeed if they are perceived to be legitimate by a substantial percentage of the citizenry. ${ }^{97}$ Experience has shown that arguments for the conservation of ecosystems or ecological processes often fail to find favour with a broad base of citizens engaged in the cares and intricacies of day-to-day living. In a striking contrast, experience has shown that the fate of certain species, especially large predators ${ }^{98}$ and other species with a perceived magnificence, may often succeed to capture the imagination of the public. The use of such a well-chosen species as a flagship of a broader conservation initiative may contribute to the harnessing of significant political and popular support. As an apex predator in the Amazon, and as the largest eagle species in the world, the Harpy Eagle is a suitable flagship species for the Amazon. It has the potential to capture the imagination of indigenous people living in the Amazon, policy-makers at state and national level, and conservationists and ecotourists internationally. ${ }^{99}$

94 Glazewski and Du Toit Environmental Law in South Africa (2013) par 14 7; Kidd Environmental Law (2011) 9.

95 Donázar et al 'Roles of raptors in a changing world: from flagships to providers of key ecosystem services' 2016 63(1) Ardeola 191-195; Simberloff 'Flagships, umbrellas and keystones: is single-species management passé in the landscape era?' 1998 Biological Conservation 248-251.

96 Simberloff 1998 Biological Conservation supra $\mathrm{n} 95$ at 250.

97 Crawford and Pignataro 2007 39(1) University of Miami Inter-American Law Review supra $\mathrm{n} 22$ at 64-65.

98 In a North American context, Simberloff 1998 Biological Conservation supra n 95 at 250 mentions the Florida panther Puma concolor coryi as a quintessential flagship species.

99 See eg Trinca, Ferrari and Lees 200830 Cotinga supra n 17 at 13; Beletsky Global Birding (2010) 121; Couzens Top 100 Birding Sites of the World (2015) 226-227. It is noteworthy that Stone, in his controversial yet influential essay 'Should trees have standing - toward legal rights for natural objects' 197245 S Cal LR 476 found it expedient to bring eagles into a habitatcentred argument: 'I am proposing we do the same with eagles and wilderness areas as we do with copyrighted works, patented inventions, and privacy: make the violation of rights in them to be a cost by declaring the 'pirating' of them to be the invasion of a property interest. If we do so, the net social costs the polluter would be confronted with would include not only the extended homocentric costs of his pollution ... but also to the environment per se.' 
Incidentally, a focus on the intrinsic value of the Amazon as the world's largest rainforest, and its importance as habitat of the Harpy Eagle and many other species, should not obscure an important international dimension of the conservation of rainforests in general and the Amazon in particular. Scientists have presented evidence that rainforests can play an important role in the mitigation of climate change by storing carbon on a large scale. ${ }^{100}$ The benefit of effective conservation of the Amazon would, therefore, reach far beyond the borders of Brazil and its South American neighbours. ${ }^{101}$ The conservation of the Amazon is really in the interest of all the nations of the world. ${ }^{102}$

\section{Conclusion}

Reflecting on the Harpy Eagle and the Amazon rainforest, two giants of nature, and their vulnerability to the exploits of humans, produces key insights in respect of the conservation of birds of prey and their habitats. In respect of the legal conservation of birds of prey in general, one could conclude that the legal protection of habitat will benefit the conservation of birds of prey, while the legal protection of 'charismatic' bird of prey species, whether in their ecological role of apex predators or their emblematic role as flagship species, may well benefit the conservation of habitats.

100 Malhi et al 'Climate change, deforestation, and the fate of the Amazon' 2008319 Science 169-172; Shukla, Nobre and Sellers 'Amazon deforestation and climate change' 1990247 Science 1322-1325. The other side to the coin is that rainforests of the world are themselves negatively impacted by climate change; Malhi 'Exploring the likelihood and mechanism of a climate-change-induced dieback of the Amazon rainforest' 2009106 Proceedings of the National Academy of Science 20610-20615; Nazareno et al 'Serious new threat to Brazilian forests' 2011 26(1) Conservation Biology 6; Phillips and Brienen 2015 'Amazon carbon sink is in decline as trees die off faster' http://theconversation.com/amazon-carbonsink-is-in-decline-as-trees-die-off-faster-38946 (accessed 2017-03-23).

101 Supra $\mathrm{n} 6$ at 2.

102 This simply-stated proposition gives rise to a magnitude of conceptual and practical legal challenges that are beyond the scope of this contribution, but see eg Atapattu 'Climate change, differentiated responsibilities and state responsibility: devising novel legal strategies for damage caused by climate change' in Richardson et al (eds) Climate Law And Developing Countries (2009) 37-58; supra n 6 at 1-3; Garcia The Amazon From An International Law Perspective (2011) 74-326; Eikermann Forests In International Law: Is There Really A Need For An International Forest Convention? (2015) 27-188; Gillespie Conservation, Biodiversity And International Law (2011) 167; Sand 'A century of green lessons: the contribution of nature conservation regimes to global governance' 20011 International Environmental Agreements: Politics, Law And Economics 33-72; Sindico 'Climate and trade in a divided world: can measures adopted in the North end up shaping climate change legislative frameworks in the South?' in Richardson et al (eds) Climate Law And Developing Countries (2009) 361-379; Wiener 'Something borrowed for something blue: legal transplants and the evolution of global environmental law' 2001 Ecology Law Quarterly 12951371. 
As seen, the legal conservation status of the Harpy Eagle as a species in Brazilian federal law is satisfactory. A comprehensive body of legislation is in place to regulate utilisation and conservation of the Amazon and other biomes, but concerns over its effectiveness have arisen, especially in the wake of the new Forest Code. A healthy legal status does not necessarily imply a healthy factual conservation status. The agribusiness backlash and the subsequent downgrading of protection under the Forest Code, as well as shortcomings in enforcement, illustrate clearly that the effect of good environmental law and policy can be diluted or neutralised if state and citizen do not act in concert and with dedication. In Brazil, such dilution has produced a rather ironic outcome in so far as the law makes it easier, in many instances, lawfully to destroy rainforest habitat than to shoot a wild animal.

Finally, the conservation threats against the Amazon rainforest should be a matter of concern to the international community. The new frontier in the legal conservation of species and their habitat is one that transcends the boundaries of states and national legal systems. Effective legal protection of species and habitats will increasingly require international cooperation. Eagles and other birds of prey, that can cross international boundaries so effortlessly, should remind us of this reality. 